\title{
Information Sharing Regulation Introduction and Bank Industry Performance: A Pre and Post Analyses from Ghana
}

\author{
Baah Aye Kusi ${ }^{1}$, Kwadjo Ansah-Adu ${ }^{2}$, Isaac Owusu-Dankwa ${ }^{2}$ \\ ${ }^{1}$ University of Ghana Business School, Department of Finance, Ghana-Accra, Legon \\ ${ }^{2}$ Valley View University Banking and Finance Department, Ghana-Oyibi

\section{Email address:} \\ baakusi@gmail.com (B. A. Kusi),joe_thwart@yahoo.co.uk(K. Ansah-Adu), iodankwa@yahoo.com (I. Owusu-Dankwa)
}

\section{To cite this article:}

Baah Aye Kusi, Kwadjo Ansah-Adu, Isaac Owusu-Dankwa. Information Sharing Regulation Introduction and Bank Industry Performance: A Pre and Post Analyses from Ghana. Journal of Finance and Accounting. Vol. 3, No. 5, 2015, pp. 164-171. doi: 10.11648/j.jfa.20150305.18

\begin{abstract}
This study assessed credit growth, asset quality and profitability in the banking industry of Ghana during pre and post information sharing eras. The study employed industry level financial ratios to derive means, standard deviations and pearson correlations. The study further employed t-test to test for significant difference in bank performance during pre and post information sharing ears. The results indicate that the Ghanaian banking industry improved in all profitability measure during post-information sharing era. Also, deteriorating asset quality measures were stabilized during post-information sharing era. Furthermore, the study finds that there was a significant difference in non - performing loans ratio in the two information sharing eras. These findings are consistent with earlier findings. Hence the study recommends the establishment of Information Sharing Institutions (ISI), expanding the coverage of ISI and publicizing information sharing in emerging economies so as to strengthen the stability and soundness of the banking system.
\end{abstract}

Keywords: Information Sharing, Credit Growth, Asset Quality, Profitability and Financial Ratios

\section{Introduction}

Financial institutions, especially banks are very sensitive and important to the development and growth of many economies (Crotty, 2008). Banks through the performance of functions such as mobilization of savings, evaluation of projects and resource allocation, management of risk, monitoring of managers and facilitation of transactions create and increase value in the economy (Gumra, 2009; Bekuert et al, 2005). However, due to the highly sensitive nature of financial institutions which could lead to a potential damage on the economy (see Karbo and Adamu 2009; Becks and Levine 2004), banks have been under serious scrutiny by both academics and practitioners (Fujii, Managi and Matousek, 2014).Hence to ensure that financial institutions are functioning effectively, many reforms and regulations are introduced in different financial systems across the globe (see Bouyon 2014; Vickers 2012; Kumbirai and Webb, 2010; Gilbert, Calitz and Plessis 2009; Muride and Yaseen 2006). Bouyon (2014) argues that banking reforms and regulations have two main objectives: financial stability objectives and economic efficiency objectives.In recent times especially in Africa (where most countries are developing economies), information sharing regulations has become one of the relevanttools for credit risk management and credit extension to the poor (Luoto et al., 2007).

Ghana is reported to be one of the few economies in West Africa to introduction information sharingregulation along side with Nigeria and Seri-Leon (World Bank, Doing Business Indicators, 2012).The financial sector of Ghana has seen a number of reforms and regulationsintroductions to ensure financial stability and economic efficiency. Prominent among these reforms and regulations introduction in Ghana is the information sharing regulation in 2010. Banks in Ghana through Credit Referencing Bureaus (CRBs) share information on bank clients (both corporate and individual borrowers and depositors) to ascertain a complete and comprehensive worthiness status of bank clients to enable them (bank) arrive as a loan or credit decision. Theories and empirical studies in developed economies however suggests that information sharing improves credit risk (Brown and Zehnder 2007; Brown et al., 2009; Bennardo et al., 2009), credit growth (Djankov et al. 2007, Brown, Jappelli and Pagano 2009;Behr and Sonnekalb 2012) and profitability 
(Bennardo et al., 2009; Behr and Sonnekalb 2012).

Indeed, performance trends (see overview section) in the Ghanaian banking sector show improvements in bank credit growth, asset quality and profitability after the introduction of information sharing regulation.However, it is not clear if the improvements are due to randomness. This study therefore provides evidence from Ghana (a developing economy), on how bank industry performance differ before and after the information sharing regulation introduction. Also, the study cites fewer studies on the effect of reforms and regulations on banks in Ghana. Hence, this study contributes to the scanty body of empirical studies on reforms and regulations effects in Ghana.Again,given the positive effects (as argued in theory and empirical findings) of information sharing, this study is overly important as it can help the economy of Ghana to expand credit delivery to help alleviate poverty; hence attaining a developed market status.The study therefore seeks to ascertain if there is a significant difference in bank performance before and after the introduction of information sharing.

\section{Overview Banking Ghana}

The Central Bank of Ghana was established in 1957 and charged with the responsibility of overseeing, supervising and regulating the operations of all Banks in Ghana. At the time of commencement only three banks (namely Barclays Bank, Standard Bank and Bank of Gold Coast) operated in Ghana. However after fifty-eight (58) years, the Ghanaian banking industry made up of twenty-seven (27) banks with foreign banks dominating the local banks in numbers. Presently, fifteen (15) out of the twenty-seven (27) banks are foreign banks while the remaining twelve (12) are local or domestic banks (Bank of Ghana 2014, Pricewaterhouse Coopers, 2014). To ensure the soundness and effective operation of the banking sector several reforms and regulations have been introduced to this effect. The table below summarizes the reforms and regulations introduced in Ghana from 2000 to 2010 .

Table 1. Summary of Major Reforms and Regulations induced in Ghana from 2000 to 2010.

\begin{tabular}{|c|c|}
\hline Year & Major Reforms and Regulations Introduction Events \\
\hline 2000 & $\begin{array}{l}\text { losure of three insolvent banks: Bank for Housing and Construction, Cooperative Bank and Bank of Credit and Commerce and transfer of } \\
\text { uaranteed deposits. }\end{array}$ \\
\hline \multirow[t]{2}{*}{2002} & $\begin{array}{l}\text { Bank of Ghana Act (2002) was passed to give independence to the central bank, Bank of Ghana, making price and financial stability as its primary } \\
\text { function. }\end{array}$ \\
\hline & Introduction of Real Time Gross Settlement (RTGS) System also known as the Ghana Interbank Settlement System. \\
\hline \multirow[t]{2}{*}{2003} & $\begin{array}{l}\text { The universal banking license was introduced and as a result Bank of Ghana issued a directive requiring all banks to increase their minimum stated } \\
\text { capital requirements to GHф7million by the end of } 2006 \text { from GHф20thousand. }\end{array}$ \\
\hline & The Payment System Act (2003) gave explicit powers to the Bank of Ghana to oversee payments system. \\
\hline 2004 & $\begin{array}{l}\text { Banking Act } 2004 \text { replaced the Banking Law } 1989 \text {. Bank of Ghana began to strengthen its risk based prudential supervision policies. In addition, } \\
\text { the minimum capital adequacy ratio was increased from } 6 \% \text { to } 10 \% \text {. } \\
\text { Bank of Ghana introduced a paper-based credit clearing system. }\end{array}$ \\
\hline \multirow[t]{2}{*}{2006} & Foreign Exchange Act 2006 - to liberalize inflows of foreign exchange into Ghana for foreign direct investment purposes. \\
\hline & Abolition of secondary deposits reserves requirement (15\%) by banks \\
\hline \multirow[t]{5}{*}{2007} & Banking Amendment Act 2007 - to allow offshore banking; to enable establishment of international financial services in Ghana. \\
\hline & $\begin{array}{l}\text { The Credit Reporting Act (Act 726) was enacted to establish credit reference bureau to offer a legal and regulatory framework for credit reporting } \\
\text { in Ghana. }\end{array}$ \\
\hline & $\begin{array}{l}\text { The International Financial Reporting Standards (IFRS) was introduced and all banks were to report their financial position and performance in } \\
\text { accordance with IFRS. }\end{array}$ \\
\hline & Implementation of risk-based supervision of banks. \\
\hline & ion f the Cadi: 1 \\
\hline \multirow[t]{3}{*}{2008} & The Anti-Money Laundering Act, 2007 (Act 749) enacted to provide structure for criminalizing money laundering. \\
\hline & $\begin{array}{l}\text { The Borrowers and Lenders Act (2008) was enacted to provide a framework for full disclosure in creditor and borrower relations and in particular } \\
\text { the role of collateral in the delivery of credit. }\end{array}$ \\
\hline & Operation of a common electronic platform, the National Switch (e-zwich) and a biometric smartcard. \\
\hline 2009 & $\begin{array}{l}\text { The ChequeCodeline Clearing }(\mathrm{CCC}) \text { was introduced which reduced the cheque clearing period from } 5-8 \text { days to } 2 \text { days throughout the country. } \\
\text { Minimum capital requirement was increased from } 7 \text { million cedi to } 60 \text { million cedi in order to strengthen the capital base of the banks to enable } \\
\text { them assume greater levels of risk. Mobile payment services were authorized and launched. }\end{array}$ \\
\hline \multirow[t]{3}{*}{2010} & Commencement of electronic direct credit transfer system a component of the Automated Clearing House project. \\
\hline & First Credit Reference Bureau started operations in Ghana \\
\hline & Sources: Bank of Ghana Reports and International Monetary Fund Country Reports. \\
\hline
\end{tabular}

After the commencement of information sharing through CRBs in Ghana in 2010, XDS Data Credit CRB enjoyed the opportunity of being the only recognized information sharing institution until latter part of 2013. Hudson Price and Dun and Bradstreet Credit Bureau Limited added up in 2013 and 2014 respectively making a total of three CRBs in Ghana presently.

\section{Literature Review}

Information sharing in the credit market is a comparatively new concept in most emerging markets (Luoto et al., 2007). Several benefits are listed to be associated with information sharing in the credit market and these benefits include improve in asset quality, credit growth and profitability. 
First, empirical findings project that information sharing improves asset quality. Studies that evaluate the effect of information sharing on bank asset quality argue that information sharing has two main effect on asset quality: screening and incentive effects (Brown et al., 2009; Luoto et al., 2007; Djankov et al., 2007). First, the screening effect suggest that information sharing enables have access to high quality and comprehensive information on bank clients for evaluating and identifyinggood borrowers from bad borrowers. Hence, this enhances the default predictive power of banks and making them more robust to adverse selection (Pagano and Jappelli, 1993). This implies that in the presence of information sharing only good borrowers (credit worthy bank borrower) have access to credit; hence improving bank asset quality. Second, the incentive effect suggest that bank clients are motivated to repay or service loans in the presence of information sharing because of the fear of future denial of loan or credit by lenders. Since default information is sharing among lenders, default with one lender is captured and shared by all lenders. Hence, lenders will deny or reduce defaulter's credit until defaulters settle their credit debts. Hence, information sharing pressured bank borrowers to settle their loans because of denial of credit in the future (Padilla and Pagano, 2000). Empirical studies that provide evidence in support of a positive link between information sharing and asset quality includes Kallberg and Udell (2003), Bennardo, Pagano and Piccolo (2009), Brown and Zehnder (2007), Luoto et al. (2007).

Second, information sharing and credit growth has also been in the spot light especially in Africa where obstacles to credit are most present. In brief, findings on information sharing and credit growth argue that, sharing information helps to extend credit or finance to poor but credit worthy borrowers who do not have collateral because the decision to advance credit is not solely based on borrower's ability to provide adequate collateral thereby reducing collateral constraints. This therefore suggests that in presence of information sharing in the credit market, credit growth increases as collateral constraints are reduced. Empirical studies that provide evidence on information sharing and credit growth includes Love and Mylenko (2003), Berger, Frame and Miller (2005), Djankov et al. (2007), Brown, Jappelli and Pagano (2009), andBehr and Sonnekalb (2012).

Finally, information sharing is argued to influence profitability in three ways. First, since credit losses are charged to the income statement of banks are expenses for the period this reduces the profit for the period. Second, since information sharing is done by specialized institutions (Credit Referencing Bureaus), these institutions are able to examine, evaluate and report accurate worthiness of bank clients at a lower unit cost through economies of scale and scope. This reduces the evaluation and monitoring cost of banks on borrowers and hence increases bank profitability. Third, since information sharing pressures bank borrowers to repay their loans (Padilla and Pagano, 2000; Brown and Zehnder 2007; Luoto et al., 2007; Bennardo, Pagano and Piccolo 2009) interest income of banks will increase and hence improving bank profitability.

\section{Methodology}

The study employs yearly industry level data from Bank of Ghana Financial stability Reports covering the periods of 2006 to 2014.Using the financial ratios computed in these Reports, the study employs descriptive statistics measures such as mean, standard deviation, minimum and maximum values to draw inferences. Also, to test for statistical difference in bank industry performance before and after information sharing regulation to ensure that difference in statistical measures are not due to randomness and chance, the study employs student t-test. To test the statistical difference in means for the seven bank industry measures, 2006 to 2009 is classified as pre information sharing era and 2011 to 2014 also classified as post information sharing era. The hypothesis to be tested for all seven performance measures stated is as:

$$
\mathrm{H}_{0}: \mu_{1}=\mu_{2}
$$

Where $\mu_{1}$ is the mean for pre information sharing era (2006 to 2009) and $\mu_{2}$ is the mean for post information sharing era. Inferences about the hypothesis are made by evaluating the statistic and critical values associated with the mean values. The null hypothesis is rejected if $p$-value $\leq \alpha$ while the alternate hypothesis is not rejected if $\mathrm{p}$-value $>\alpha$. Rejecting the null hypothesis will indicate that the means for pre and post information sharing eras are different; hence leading to a possible effect of Information sharing on bank performance. Financial ratios are used for a number of reasons. First, Hemple et al. (1994) and Dietrich (1996) suggest that financial ratios give a clear picture of events and early signs of danger for effective planning to correct the perceived danger. Second, size effects are avoided by the use of financial ratios since they are points of concern for the t-test tool (See Samada 2004). Third, since non-linearity is a key consideration under t-test statistical tool, the employment of financial ratios curtails such non-linearity issues (see Brooks 2008; Wooldridge 2008).

\subsection{Variable Definition and Selection}

The variable selection for this study is principally based earlier empirical findings on information sharing and key bank performance measures employed in assess banks in Ghana by the Bank of Ghana. Since earlier empirical studies suggest that information sharing affects bank credit growth, asset quality and profitability, the study selects variables of such indications from Bank of Ghana Financial Stability Reports to achieve the objectives of this study. These performance measures are discussed below.

\subsection{Credit Growth}

Credit Growth is calculated as the current year's total loans and advances minus the previous year's total loans and advances divided by the total loans and advances for the 
previous year. This measures that growth in bank loan and advances on a yearly bases.

\subsection{Asset Quality}

Asset quality is an indicative measure showing how well the banking industry is free from credit risk exposure emanating from the core business of banking. The study employs three different asset quality measures used by the bank of Ghana. These measures are discussed below:

Non-Performing Loans (NPL ratio)

NPL ratio is computed as the summation of past unpaid loans divided by the total loans and advances granted in a given year. This gives a percentage indication of how much unpaid loans constitutes total loans and advances in a give years. Lower values of NPL ratios are desirable as it indicates lower non-performing assets.

\section{Loan Loss Provision (LLP ratio)}

LLP ratio is computed as a function of projected or estimated credit losses based on previous the years credit losses divided by total loans and advances in a given year. It shows the proportion of loans and advances that constitutes projected credit losses in a given year. As NPL ratio, lower values of LLP ratio are favorable as it indicates lower credit losses.

Non-Performing Loans net Provision to Capital (NPL to Capital ratio)

NPL to Capital ratio is calculated as non-performing loans minus loan loss provisions divided by total capital or equity in a given year. This indicate how much of bank capital constitutes credit losses in a given year. As NPL ratio and LLP ratio, lower values of NPL to Capital ratio are preferred because it is an indication of low credit losses.

\subsection{Profitability}

Bank profitability is captured in this study with three key profitability measures used in most empirical studies. They include net interest margin, return on equity and return on assets. They are discussed in brief.

Net Interest Margin (NIM)

NIM is a bank profitability indicator and computed as interest income minus interest expenses divided by total assets. This shows the proportion of bank core or main income generated by the assets of the banks. Higher values of NIM are desirable as it indicates profitable and efficiency use of bank assets.

\section{Return on Equity (ROE)}

ROE is calculated as net income divided by total bank equity or capital. This bank profitability measure indicates the return to shareholders or equity-holders of a bank. High values of ROE are indications for shareholder value maximization and high values are preferred to low values.

Return on Assets (ROA)

ROA is a bank profitability measure that is computed as earnings before interest and tax divided by total assets. This profit measure also indicates how well the assets of banks have been employed to generate income. It shows the reward or return to all stakeholders (including debt-holders, equityholders and the State) and higher values are always preferred to lower values.

\section{Results}

\subsection{Industry Performance Before and After Information Sharing Introduction}

The study highlights three key bank performance indicators before and after introduction of information sharing in the Ghanaian banking sector. These key performance indicators include bank credit growth, asset quality and profitability. However, the study discusses three different measures of bank industry profitability and asset quality.

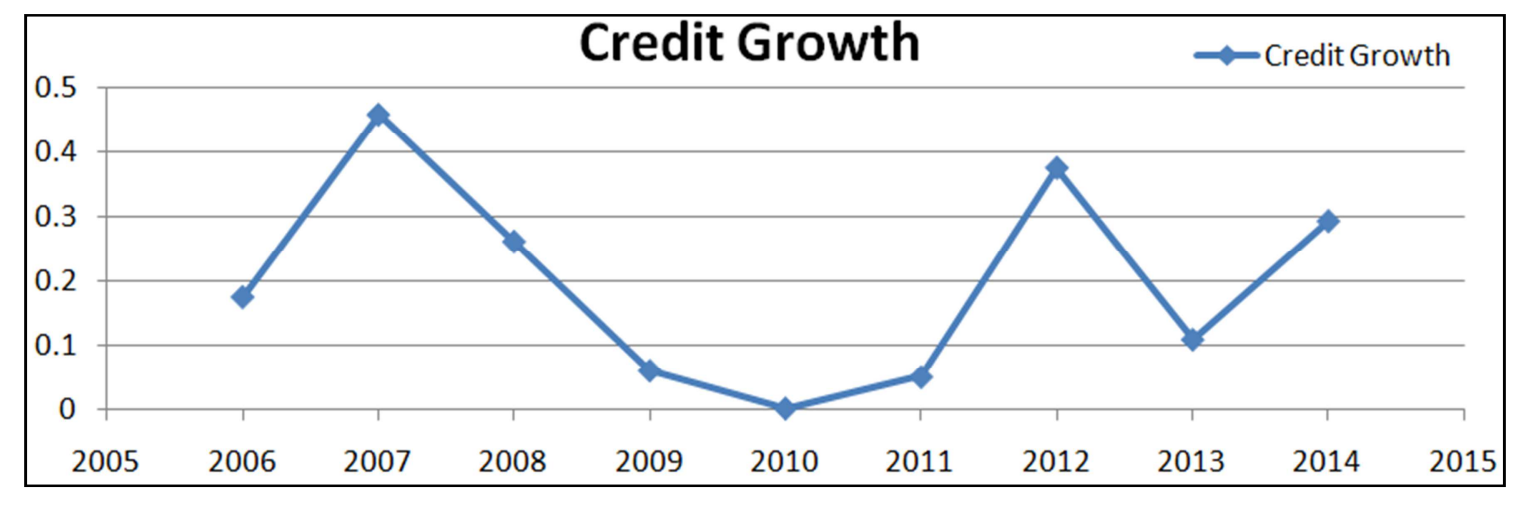

Source: Plotted from Figures in Bank of Ghana Stability Reports (2013 and 2014).

Figure 1. Bank Industry Credit Growth Trend from 2006 to 2014 in Ghana.

Figure 1 presents the bank industry credit growth trend in Ghana from 2006 to 2014. The industry credit growth figures are sourced from Bank of Ghana Financial Stability reports (2013 and 2014). From the plotted graph though bank industry credit growth increased from $17.5 \%$ in 2006 to
$45.6 \%$ in 2007 ; it subsequently took a continuous nose dive from 2007 through to 2010 where information sharing regulation took effect in Ghana. However from 2010 where industry credit growth was $0.025 \%$, industry rose to $5.12 \%$ in 2011 and further rose to $37.4 \%$ in 2012 . However industry 
credit growth decreased to $10.94 \%$ in 2013 but rose again in 2014 to $29.26 \%$. This trend suggests improvements in bank industry credit growth in Ghana after the introduction of information sharing among banks.

Figure 2 also presents the bank industry asset quality trends in Ghana from 2006 to 2014 using three (3) different measures for asset quality namely: non-performing loans ratio (NPL ratio), loan loss provision ratio (LLP ratio) and non-performing loans to capital ratio (NPL to Capital). The industry asset quality figures are sourced from Bank of Ghana Financial Stability Reports (2013 and 2014). From the above graph bank industry asset quality improved from 2006 to 2007 for all the asset quality measures with NPL ratio being the worst asset quality measure. However, all three asset quality measures continuously deteriorate from 2007 to 2010 where asset quality measures reached their peak for the periods understudy. However, after the introduction of information sharing through credit referencing bureaus in Ghana, the three measures for asset quality has persistently improved from 2010 to 2014 . The above trends industry asset quality suggests improvements in asset quality in Ghana after the introduction of information sharing among banks compared before information sharing regulation introduction. The three measures for asset quality displays similar trends as shown the Figure 2 above.

Figure 3 as well illustrate the trends in bank industry profitability in Ghana from 2006 to 2014 employing three (3) different indicator measures for bank industry profitability namely: net interest margin (NIM), return on equity (ROE) and return on assets (ROA). The industry profitability figures are taken from Bank of Ghana Financial Stability Reports (2013 and 2014). From the above plotted profitability graph, NIM, ROE and ROA consistently declines from 2006 to 2009. The three (3) profitability measures however improved from 2009 to 2010 where information sharing is introduced in the Ghanaian banking sector but they again reduced in 2011. However, NIM, ROE and ROA consistently improved beyond 2011. From the bank industry profitability trends it appears all the profitability indicators improved consistently one year after the introduction of information sharing in Ghana. Furthermore, all the three (3) profitability measures illustrate similar trends over the periods understudy.

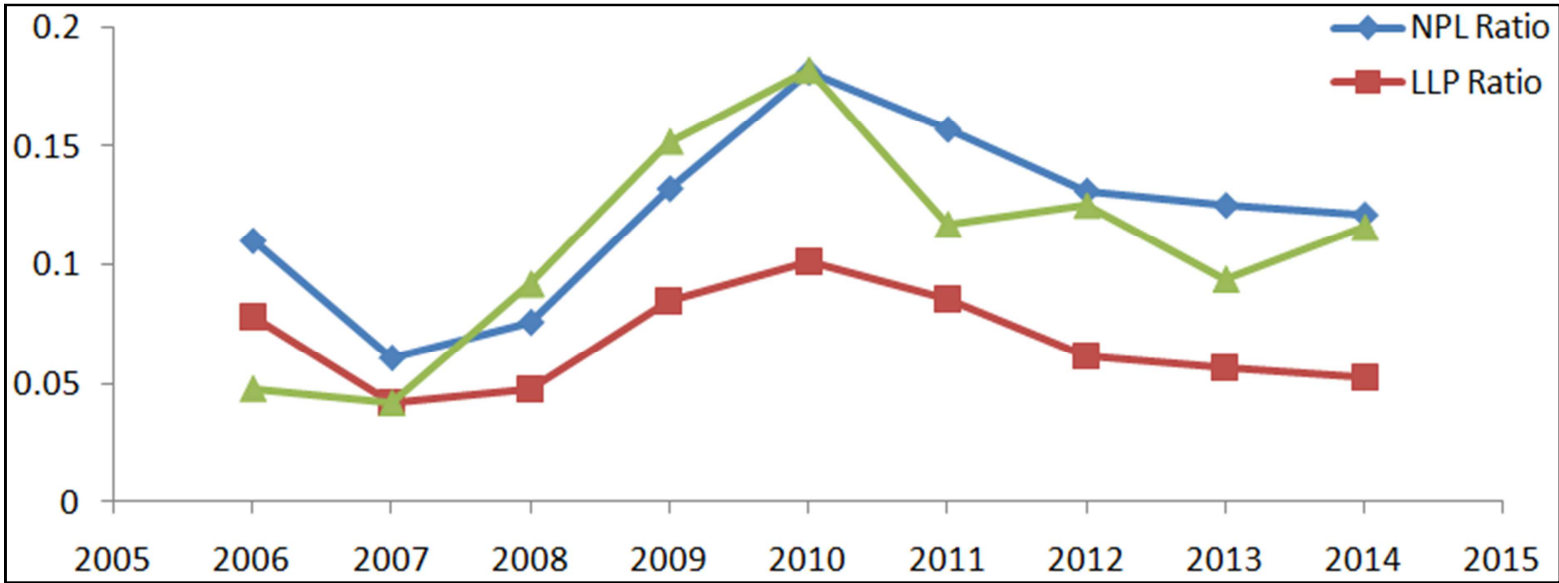

Source: Plotted from Figures in Bank of Ghana Stability Reports (2013 and 2014).

Figure 2. Bank Industry Asset Quality Trends from 2006 to 2014 in Ghana.

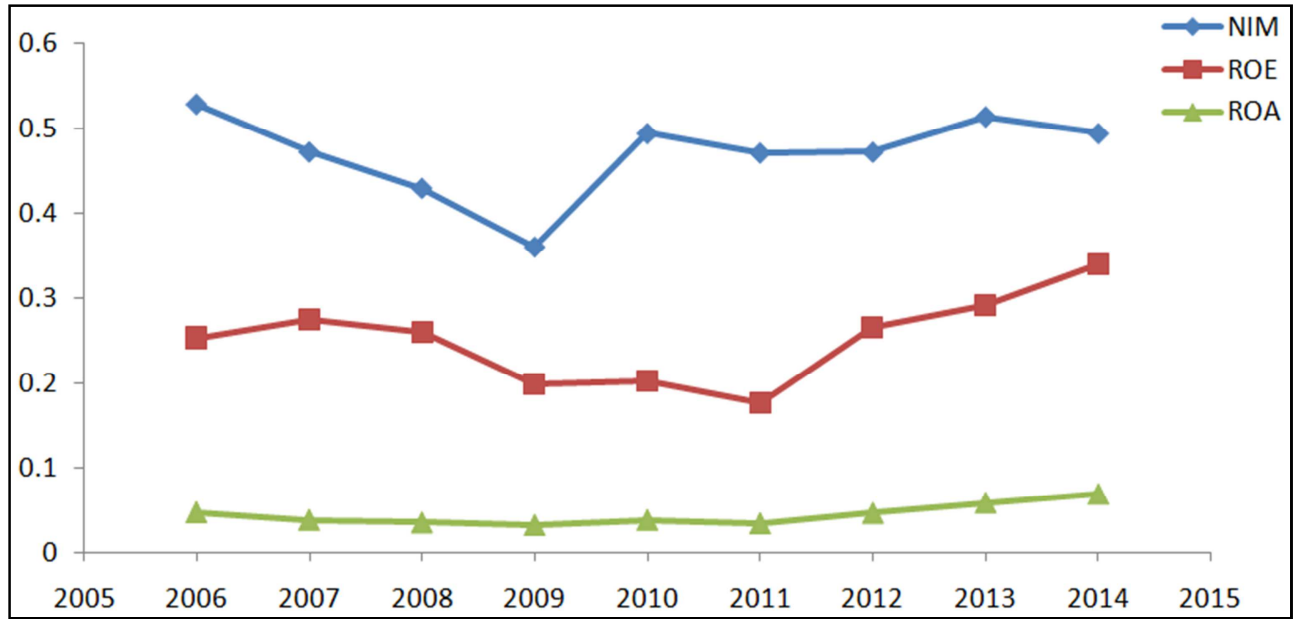

Source: Plotted from Figures in Bank of Ghana Stability Reports (2013 and 2014).

Figure 3. Bank Industry Profitability Trends from 2006 to 2014 in Ghana. 
Table 2. T-Test Results on Pre and Post Information Sharing Eras.

\begin{tabular}{|c|c|c|c|c|c|c|c|}
\hline $\begin{array}{l}\text { Performance } \\
\text { Indicator }\end{array}$ & $\begin{array}{l}\text { Pre-Information } \\
\text { Sharing Era } \\
\text { Mean }\end{array}$ & $\begin{array}{l}\text { Post-Information } \\
\text { Sharing Era Mean }\end{array}$ & $\begin{array}{l}\text { Pearson } \\
\text { Correlation }\end{array}$ & $\begin{array}{l}\text { Pre-Information } \\
\text { Sharing Era } \\
\text { Standard Deviation }\end{array}$ & $\begin{array}{l}\text { Post-Information } \\
\text { Sharing Era } \\
\text { Standard Deviation }\end{array}$ & P-Value & Decision \\
\hline $\begin{array}{l}\text { Credit Growth } \\
\text { Asset Quality }\end{array}$ & 0.2383 & 0.2068 & 0.3801 & 0.1667 & 0.1517 & 0.3734 & Accept \\
\hline NPL & 0.0948 & 0.1335 & 0.0872 & 0.0322 & 0.0162 & $0.0560 *$ & Reject \\
\hline LLP & 0.0633 & 0.0645 & 0.2467 & 0.0214 & 0.0148 & 0.4598 & Accept \\
\hline $\begin{array}{l}\text { NPL to } \\
\text { Capital } \\
\text { Profitability }\end{array}$ & 0.0835 & 0.1130 & -0.3012 & 0.0508 & 0.0133 & 0.1860 & Accept \\
\hline NIM & 0.4473 & 0.4878 & -0.6338 & 0.0717 & 0.0205 & 0.2082 & Accept \\
\hline ROE & 0.2463 & 0.2683 & -0.5643 & 0.0333 & 0.0683 & 0.3315 & Accept \\
\hline ROA & 0.0380 & 0.0515 & -0.9637 & 0.0065 & 0.0147 & 0.1448 & Accept \\
\hline
\end{tabular}

Significance Level: $(*)<10 \%,(* *)<5 \%$ and $(* * *)<1 \%$

\subsection{Credit Growth in Pre and Post Information Sharing Eras}

With regards to credit growth performance indicator, it perform better by recording a mean growth rate of $23.63 \%$ under the pre-information sharing era compare to the post-information sharing era mean of $20.68 \%$. However, the credit growth standard deviation of $16.67 \%$ for preinformation sharing era was higher than that of the postinformation sharing era of 15.17 indicatingthat credit growth rate grew slightly stable during pre-information sharing era. The pre and post information sharing eras are positively related as indicated by the Pearson correlation. This implies that as credit growth in pre-information sharing era increases by $100 \%$, post information era credit growth will also increase by $38.01 \%$. However, the p-value of 0.3734 been higher than alpha $(\alpha)$ values of $0.01,0.05$ and 0.1 suggest evidence of no statistical significant difference in Credit growth during pre and post information sharing eras. Hence, the study unable to concludes that information sharing affect credit growth. This finding is cost with Behr and Sonnekalb (2012) who found no evidence in support that information sharing affect credit growth and cost to finance but found evidence to support the view that information sharing improved loan performance (repayment of loans) in banks in Albania.

\subsection{Asset Quality in Pre and Post Information Sharing Eras}

Non-performing loans (NPL ratio), loan loss provision and non-performing loans net provisions to capital recorded lower mean values of $9.48 \%, 6.33 \%$ and $8.35 \%$ respectively during pre-information sharing era as compared to the postinformation sharing era mean values of $13.35 \%, 6.45 \%$ and $11.30 \%$ respectively. This indicates that asset quality is deteriorated during post information sharing era. However, NLP ratio, LLP ratio and NPL to Capital ratio were very stable during the post-information sharing era with standard deviation values of $1.62 \%, 1.48 \%$ and $1.33 \%$ as compared to pre-information NPL ratio, LLP ratio and NPL to capital ratio values of $3.22 \%, 2.14 \%$ and $5.08 \%$. This indicates that asset quality deterioration was moderately slow and small during post-information sharing era. NPL and LLP during the two Eras are positively related implying that a unit increase in NPL and LLP leads to $8.72 \%$ and $24.47 \%$ increase in NPL and LLP respectively. Following Chaibi and Ftiti (2015) who argue that NPL and LLP are backward and forward looking respectively and rely on past credit default records to attain values for NPL and LLP, it is not surprising that these two are positively related in the two information sharing eras. However, NPL net provision provides a value of current asset quality which reflect present credit losses; hence a negative correlation between the two information sharing eras. With pvlaues of 0.4598 and 0.1860 , the study fails to reject the null hypothesis that the mean for the two information sharing ears are the same and conclude that there is no statistical significant difference in LLP and NPL to Capital during pre and post information sharing eras. Howeverwith a p-value of 0.0560 , NPL ratio suggests evidence of statistical significant difference at $10 \%$ between pre and post information sharing eras.This finding is consistent with Behr and Sonnekalb (2012), Bennardo, Pagano and Piccolo (2009), Brown and Zehnder (2007) and Luoto et al. (2007) who argue that banks are able to improve or reduce asset quality deterioration in the presence of information sharing.

\subsection{Profitability in Pre and Post Information Sharing Eras}

With regards to bank profitability, NIM, ROE and ROA appear to have performed better during post-information sharing era as they recorded $48.78 \%, 26.83 \%$ and $5.15 \%$ respectively compared to pre-information sharing era values of $44.47 \%, 24.63 \%$ and $3.80 \%$ respectively. This provides evidence to support the view that banks are able to improve their profitability in the presence of information sharing (Behr and Sonnekalb 2012; Luoto el at., 2007). ROE and ROA recorded lower percentages of standard deviations in pre-information sharing era of $3.33 \%$ and $0.65 \%$ respectively compared to post-information sharing era ROE and ROA percentages of $6.83 \%$ and $1.47 \%$ respectively. This is an indication that ROE and ROA were quite unstable and less predictable during post-information sharing era. However, NIM gained less instability of $2.05 \%$ during post-information sharing era compared to $7.17 \%$ instability in the preinformation sharing era. The study further reports an inverse 
relationship between pre and post information sharing eras for all the profitability indicative measures. However, with $\mathrm{p}$ values of $0.2082,0.3315$ and 0.1448 for NIM, ROE and ROA respectively, the study fails to reject the null hypothesis that there zero statistical differences in means for the pre and post information sharing eras. This leads to the conclusion that, there is no statistical significant difference in profitability in pre and post information sharing eras.

\section{Summary and Conclusion}

The study assessed the Ghanaian banking industry during the pre (2006 to 2009) and post (2011 to 2014)information sharing eras or periods. The results indicate that overall industry profitability improved in post-information sharing era and more stability during pre-information sharing era. However, asset quality is reported to be more stable and predictable during post-information sharing era but deteriorate during the same period.Specifically, NPL was statistical and significantly different from zero implying that NPL ratio differs across the pre and post information sharing era. Credit growth also appears to be higher during the preinformation sharing era but attains much stability during the post-information sharing era. These findings have policy implications and direction for emerging markets especially when these findings are emanating from an emerging economy. First, emerging economies are encouraged to institute and use the services of information sharing institutions as these institutions can help improve bank profitability and also stabilize deteriorating asset quality in the banking sector as shown in this study. Furthermore, the study recommends that the data source for information sharing institutions should be expanded to cover utility agencies, tax agencies, court rulings on financial issues and non banking financial institutions. This is recommended because information sharing covers only $12.34 \%$ (World Development Indicators, 2013) of adult population in developing or emerging countries and its impact or effect can be improved if more people are covered (see Powell et al., 2004 and Kallberg and Udell 2003). Finally, Louto et al., (2007) suggest that the publicity or awareness of information sharing institutions serves as disincentive to bank borrowers to default due to future denial for credit. Hence, the study recommends that banks make a conscious effort to sensitize their clients on information sharing since it can improve banking operations.

\section{References}

[1] Bank of Ghana. (February 2013). Financial stability report. Volume 5 no. 1/2013, Accra, Ghana.

[2] Bank of Ghana. (November 2014). Financial stability report. Volume 5 no. 2/2014, Accra, Ghana.

[3] Beck, T. and Levine, R., (2004). Stock Markets, Banks and Growth: panel evidence. Journal Banking and Finance. 28, 423-442.
[4] Behr, P. and Sonnekalb, S. (2012). The effect of information sharing between lenders on access to credit, cost of credit and loan performance - Evidence from a credit registry introduction. Journal of Banking and Finance 36 (2012) 30173032 .

[5] Bennardo, A., Pagano, M., Piccolo, S., (2009). Multiple-bank lending, creditor rights and information sharing. Mimeo, University of Salerno.

[6] Bourke, P. (1989). Concentration and other determinants of bank profitability in Europe, North America and Australia. Journal of Banking and Finance, 13(1), 65-79.

[7] Bouyon, S. (2014). The impact of Bnaking structural Reforms on Household Retail Finance. European Credit Institution Commentary No. 13.

[8] Brooks, C. (2008). Introductory Econometrics for Finance (2 $2^{\text {nd }}$ Ed.). Cambridge University press.

[9] Brown, M., and Zehnder, C., (2007). Credit reporting, relationship banking, and loan repayment. J. Money, Credit, Banking 39, 1884-1918.

[10] Brown, M., Jappelli, T., Pagano, M., (2009). Information sharing and credit: firm-level evidence from transition countries. Journal of Financial Intermediation 18, 151- 172.

[11] Crotty, J. (2008). 'Structural Causes of the Global Financial Crisis: A Critical Assessment of the New Financial Architecture', Political Economy Research Institute (PERI) Working Paper no. 180, available at www.peri.umass.edu.

[12] Dietrich, J. (1996). Financial Services and Financial Institutions: Value Creation in Theory and Practice Prentice Hall.

[13] Djankov, S., McLiesh, C., Shleifer, A., 2007. Private credit in 129 countries. Journal of Financial Economics 84, 299-329.

[14] Fujii, H., Managi, S. and Matousek, R. (2014). Indian bank efficiency and productivity changes with undesirable outputs: A disaggregated Approach. Journal of Banking and Finance $38(2014) 41-50$.

[15] Gamra, S. B. (2009). "Does financial liberalization matter for emerging East Asian economies growth? Some new evidence." International Review of Economics and Finance, 18:392-403.

[16] Gilbert, E., Calitz, E., Plessis, S., (2009). Prudential regulation, its international background and the performance of the banks a critical review of the South African environment since 1970. Economic History of Developing Regions 24 (2), pp $43-81$.

[17] International Monetary Fund. (2011). Ghana: Financial system stability assessment update. IMF Country Report No.11/131, International Monetary Fund, Washington, D. C..

[18] Jappelli, T. and Pagano, M. (2006). Role and effects of credit information sharing. In: Bertola, G., Disney, R., Grant, C.and (Eds.), The Economics of Consumer Credit. MIT Press, Cambridge, pp. 347-371.

[19] Jappelli, T., Pagano, M.and Bianco, M. (2005). Courts and banks: Effects of judicial enforcement on credit markets. $J$. Money, Credit, Banking 37, 223-244.

[20] Jappelli, T.and Pagano, M. (2002). Information sharing, lending and defaults: Cross-country evidence. J. Banking Finance 26, 2017-2045. 
[21] Kallberg, J. G. and Udell, G. F. (2003). The value of private sector credit information. J. Banking Finance 27, 449-469.

[22] Kargbo, S. M. and Adamu, P. A. (2009). Financial Development and Economic Growth in Sierra Leone. Journal of Monetary and Economic Integration 9 (2009) 2.

[23] Kumbirai, M. and Webb R. (2010). A financial Ratio Analysis of Commerial Bank Performance in South Africa. African Review of Economics and Finance Vol 2 (1).

[24] Hempel, G., Simonson, D., and Coleman, A. (1994). Bank Management: Text and Cases. 4th Edition, John Wiley \& Sons, Inc.

[25] Love I. and Mylenko, N., (2003). Credit reporting and financing constraints. World Bank Policy Research Working paper 3142 .

[26] Luoto, J., McIntosh, C., and Wydick, B., (2007). Credit information systems in less-developed countries: Recent history and a test. Econ. Devel. Cult. Change 55, 313-334.

[27] Murinde V., and H. Yaseen, (2006). The Impact of Basle Accord Regulations on Bank Capital and Risk Behaviour: 3D Evidence from the Middle East and North Africa (MENA) Region. University of Birmingham.

[28] Padilla, A. J. and Pagano, M. (2000). Sharing default information as a borrower discipline device. Europ. Econ. Rev. 44, 1951-1980.
[29] Padilla, A. J. and Pagano, M., (1997). Endogenous communication among lenders and entrepreneurial incentives. Rev. Finan. Stud. 10,205-236.

[30] Pagano, M., and Jappelli, T. (1993). Information sharing in credit markets. J. Finance 43, 1693-1718.

[31] Powell, A., Mylenko, N., Miller, M. and Majnoni, G. (2004). Improving credit information, bank regulation and supervision: On the role and design of public credit registries. Policy.

[32] Samad, A. (2004). Bahrain Commercial Bank's Performance during 1994-2001.Credit and Financial Management Review 10(1) pp 33-40.

[33] Vickers, J. (2012), "Some economics of banking reform", Department of Economics, University of Oxford, Discussion Paper Series, No. 632, November.

[34] Wooldridge, J. (2008). Introductory Econometrics: A Modern Approach, $4^{\text {th }}$ edition. Mason, OH: South-Western Cengage Learning.

[35] World Bank (2012). Doing Business Indicators in 2012. Oxford Univ. Press, Oxford. 